\title{
A Two-stage DC-DC Converter for the Fuel Cell-Supercapacitor Hybrid System
}

\author{
Zhang, Zhe; Thomsen, Ole Cornelius; Andersen, Michael A. E.
}

Published in:

IEEE Energy Conversion Congress and Exposition 2009

Link to article, DOI:

10.1109/ECCE.2009.5316065

Publication date:

2009

Document Version

Publisher's PDF, also known as Version of record

Link back to DTU Orbit

Citation (APA):

Zhang, Z., Thomsen, O. C., \& Andersen, M. A. E. (2009). A Two-stage DC-DC Converter for the Fuel CellSupercapacitor Hybrid System. In IEEE Energy Conversion Congress and Exposition 2009 (pp. 1425-1431). IEEE. https://doi.org/10.1109/ECCE.2009.5316065

\section{General rights}

Copyright and moral rights for the publications made accessible in the public portal are retained by the authors and/or other copyright owners and it is a condition of accessing publications that users recognise and abide by the legal requirements associated with these rights.

- Users may download and print one copy of any publication from the public portal for the purpose of private study or research.

- You may not further distribute the material or use it for any profit-making activity or commercial gain

- You may freely distribute the URL identifying the publication in the public portal 


\section{A Two-stage DC-DC Converter for the Fuel Cell-Supercapacitor Hybrid System}

\author{
Zhe Zhang \\ Student Member, IEEE \\ Technical University of Denmark \\ Elektrovej, building 325 \\ Kgs. Lyngby, DK 2800, Denmark \\ zz@elektro.dtu.dk
}

\author{
Ole C. Thomsen \\ Member, IEEE \\ Technical University of Denmark \\ Elektrovej, building 325 \\ Kgs. Lyngby, DK 2800, Denmark \\ oct@elektro.dtu.dk
}

\author{
Michael A. E. Andersen \\ Member, IEEE \\ Technical University of Denmark \\ Elektrovej, building 325 \\ Kgs. Lyngby, DK 2800, Denmark \\ ma@elektro.dtu.dk
}

\begin{abstract}
A wide input range multi-stage converter is proposed with the fuel cells and supercapacitors as a hybrid system. The front-end two-phase boost converter is used to optimize the output power and to reduce the current ripple of fuel cells. The supercapacitor power module is connected by push-pull-forward half bridge (PPFHB) converter with coupled inductors in the second stage to handle the slow transient response of the fuel cells and realize the bidirectional power flow control. Moreover, this cascaded structure simplifies the power management. The control strategy for the whole system is analyzed and designed. A $1 \mathrm{~kW}$ prototype controlled by TMS320F2808 DSP is built in the lab. Simulation and experimental results confirm the feasibility of the proposed twostage dc-de converter system.
\end{abstract}

Index Terms - DC-DC Converter, soft-switching, control

\section{NOMENCLATURE}

$V_{\mathrm{FC}}: \quad$ Voltage of fuel cell.

$V_{\mathrm{SC}}: \quad$ Voltage of super-capacitor.

$V_{D C}: \quad$ Voltage of high voltage $\mathrm{DC}$ bus.

$L_{1}, L_{2}$ : Inductance in the boost converter.

$L_{P 1}, L_{P 2}: \quad$ Self-inductance of the coupled inductor.

$L_{P}: \quad$ Equivalent inductance of the coupled inductors.

M: $\quad$ Mutual inductance of the coupled inductors.

$i_{L 1}, i_{L 2}: \quad$ Instantaneous current through inductor $L_{1}$ and $L_{2}$, respectively.

$i_{L P 1}, i_{L P 2}: \quad$ Instantaneous current through inductor $L_{P 1}$ and $L_{P 2}$, respectively.

$i_{s}$ : Instantaneous current through secondary winding.

$i_{\text {load }}: \quad$ Instantaneous load current.

$i_{F C}: \quad$ Instantaneous output current of fuel cell.

$i_{S C}: \quad$ Instantaneous output current of supercapacitor.

$v_{A B}$ : Instantaneous voltage across the auxiliary inductor $L_{P 1}$ and primary winding of transformer.

$v_{C N}$ : Instantaneous voltage across the secondary winding of transformer.

$d$ : $\quad$ Duty cycle of the switches in boost converter.

$\varphi$ : $\quad$ Phase-shift angle between $v_{\mathrm{AB}}$ and $v_{\mathrm{CN}}$.

$f_{s B}: \quad$ Switching frequency of Boost converter.

$f_{s P}: \quad$ Switching frequency of PPFHB converter.

$\omega_{P}: \quad$ Angular frequency of PPFHB converter.

$P_{O}: \quad$ Output power.

$\eta_{B}$ : $\quad$ Conversion efficiency of the boost converter.

$N_{1}, N_{2}, N_{3}$ : Number of turns of two primary windings and secondary winding, respectively.

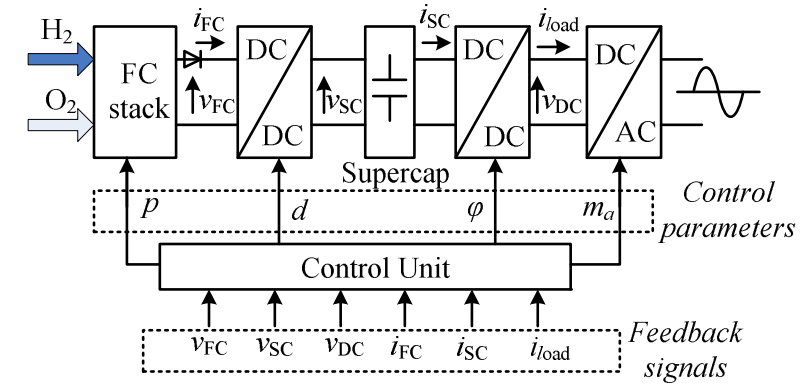

Fig. 1. Block diagram of the multi-stage energy conversion hybrid system.

\section{INTRODUCTION}

In recent years, development of the clean power sources and electricity has become an important topic to protect the environment and overcome the energy crisis of the whole world. Fuel cells (FCs) are electrochemical devices which convert the chemical potential of the hydrogen into electric power directly, with consequent high conversion efficiency and possibility to obtain the extended range with the combustible feed from the outside [1]. Based on these advantages, fuel cell is a promising substitute to the conventional fossil energy. But one of the main weak points of the fuel cell is its slow dynamics that is limited by the hydrogen and air delivery system. Thus, energy storage units, such as batteries or supercapacitors (SCs), are required as the auxiliary power sources for smoothing output power in the warming-up stage of the fuel cells or load transient period. So hybrid power conversion systems with fuel cells and other energy sources, like the system shown in Fig. 1, are used in the many industrial systems such as uninterruptible power supply (UPS), hybrid electrical vehicles (HEV) and so on.

Many hybrid system structures have been proposed. In general, they can be divided into three categories depending on different coupling method of the different power sources: DC-bus-coupled system [2], [3], [4], transformer-coupled structure [5], [6], [7], and multi-stage system [8], [9], [10]. For the DC-bus-coupled system, each power source is connected by a separate converter to the common voltage DC bus. In this architecture, every subsystem can be designed as an individual module, but the energy management and control is complicated. In high frequency transformer coupled system, the performance of system is mainly affected 


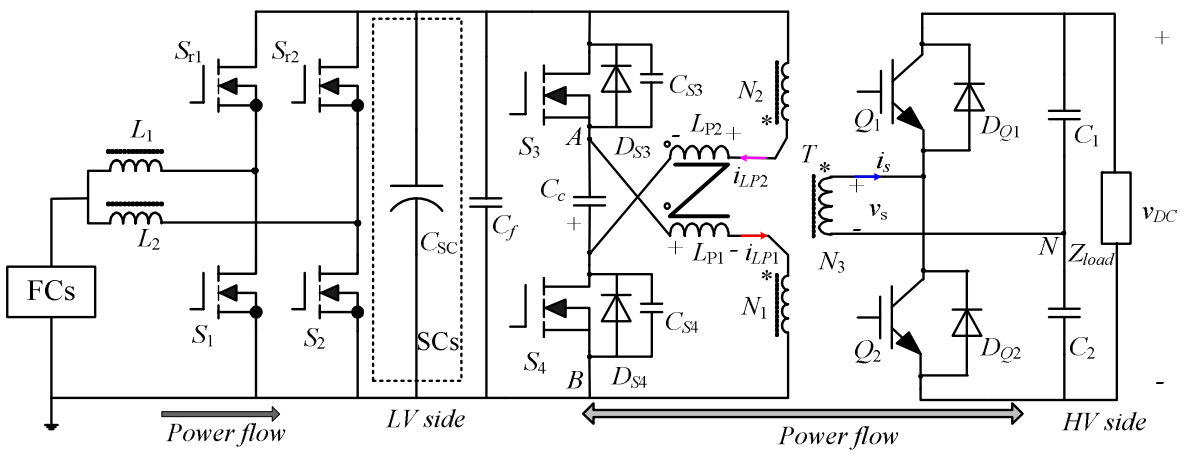

Fig. 2. The main circuit.

by the transformer design and power flow control. As to the multi-stage conversion system, efficiency of the whole system is limited by the number of cascaded converters.

In this paper, a high step-up multi-stage bidirectional isolated DC-DC conversion system with fuel cell and supercapacitor as energy sources is investigated, shown in Fig. 2, where the interleaved two-phase boost converter and push-pull-forward half bridge converter with coupled inductors are used as the interface topologies.

This paper is organized into five sections. Following the introduction, the circuits used in the system are presented in Section III. In Section IV, the control method and the stability analysis are described. Then the experimental results for a low-voltage high current power source and a supercapacitor module are provided to validate the effectiveness of the proposed conversion structure in Section V. Finally the conclusions are drawn in Section VI.

\section{SYSTEM CONFIGURATION}

As the configuration shown in Fig.1 and Fig. 2, the interleaved two-phase boost converter is used to reduce the fuel cell output current ripple and boost the fuel cell output voltage which depends on load condition, to the variable low voltage DC bus connected with supercapacitor module. Push-pull-forward half bridge (PPFHB) converter with coupled inductors [11] is used to implement the high step-up ratio, electrical isolation between the clean energies and high voltage DC bus, and the bidirectional power flow control to charge or discharge the supercapacitor module. Because of the supercapacitors decoupling the low voltage side and the high voltage side, the two-phase boost converter and PPFHB converter can be designed independently.

\section{A. Two-phase interleaved boost converter}

To reduce the input current ripple and reach high efficiency, the two-phase boost converter operates under CCM (Continuous Current Mode) in the normal load condition. The boost converter uses the MOSFETs as rectifier instead of diodes to realize "synchronous conduction mode" (SCM) [12] operation in light load condition, and the upper and lower switches are gated on-off complementarily.

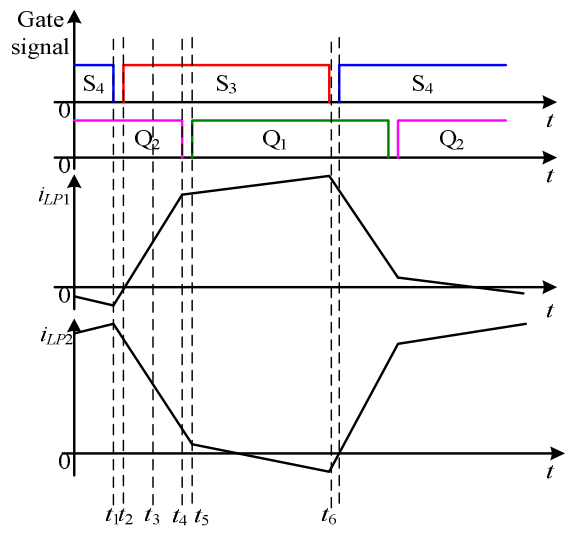

Fig. 3 Key waveforms of PPFHB converter

With the SCM operation, all switches can realize ZVS (Zero-Voltage-Switching) to make the converter achieve high efficiency in whole load range. The design of the inductors plays a crucial role in the overall converter operation, because if it is smaller, in light load condition, the current through the inductor will have bigger negative peak value (because of SCM operation, there is no DCM (Discontinuous Current Mode) operation in the converter) that will cause higher reactive power. The relationship of critical inductance (the value decides the boundary that there is negative part in the inductor current waveform or not), input voltage, output power and switching frequency can be described as:

$$
L_{c r i t}\left(v_{F C}, f_{S B}\right)=\frac{v_{F C}^{2} \cdot\left(v_{S C}-v_{F C}\right) \cdot \eta_{B}}{f_{S B} \cdot P_{o} \cdot v_{S C}}
$$

\section{B. PPFHB converter}

The proposed topology employs the push-pull-forward structure to reduce the number of the power switches; utilises the half-bridge voltage doubler circuit in the secondary side of the high frequency transformer to get high voltage transfer ratio. The auxiliary inductors, $L_{P 1}$ and $L_{P 2}$, and the leakage inductor of the transformer, $L_{l k}$, are utilized as the interface and energy transfer elements between the two high frequency voltage-source inverters on the two sides of the transformer.

The converter is controlled by the phase-shift technique to 
realize stable output voltage and bidirectional power flow between the low voltage (LV) side and high voltage (HV) side. Because the voltage cross the switches is always leading to the current in the corresponding switches, all the switches are turned on under ZVS.

Fig. 3 demonstrates the complete cycle of ideal circuit operation, where gate signals are square waveform with dead time. The gated and conducting devices in every interval are listed in Table I. The detailed description of the operation principles can be found in the paper [11] and [13]. As the conclusion drawn in [11], coupling coefficient between the two coupled inductors should not be set very near to 1 , because in that condition, the very small difference in the self inductance will cause too large unbalance between each equivalent inductance to be acceptable.

The phase shift angle $\varphi(-0.5 \pi \leq \varphi \leq 0.5 \pi)$ between $v_{\mathrm{AB}}$ and $v_{\mathrm{CN}}$, which is defined to be positive when $v_{\mathrm{AB}}$ is leading to $v_{\mathrm{CN}}$ in phase, is used to control the power flow. When $\varphi$ is positive, the power is delivered from supercapacitors to the high voltage DC bus (boost mode). If $\varphi$ is negative, the converter will work under buck mode. According to the waveforms shown in Fig. 3, the magnitude of delivered active power by this converter can be calculated as:

$$
P_{O}=\frac{N_{1} \cdot V_{S C} \cdot V_{D C}}{2 \cdot N_{3} \cdot \omega_{P} \cdot\left(L_{P}+M+L_{l k}\right)} \cdot \frac{\varphi \cdot(\pi-|\varphi|)}{\pi}
$$

So from (2) we also can get the voltage conversion ratio as:

$$
M(\varphi)=\frac{V_{D C}}{V_{S C}}=\frac{N_{1} Z_{L}}{2 N_{3} \omega_{P}\left(L_{P}+M+L_{l k}\right)} \cdot \frac{\varphi(\pi-\varphi)}{\pi}
$$

It is clear that the system is nonlinear and the output voltage is load-dependent.

TABLE I

Gated AND Conducted Switches Sequence

\begin{tabular}{c|c|c|c|c}
\hline \hline \multirow{2}{*}{ Intervals } & \multicolumn{2}{|c|}{ LV side } & \multicolumn{2}{c}{ HV side } \\
\cline { 2 - 5 } & Gated & Conduction & Gated & Conduction \\
\hline$t_{0}<t<t_{1}$ & $S_{4}$ & $S_{4}$ & $Q_{2}$ & $D_{\mathrm{Q} 2}$ \\
\hline$t_{1}<t<t_{2}$ & 0 & $D_{\mathrm{S} 3}$ & $Q_{2}$ & $D_{\mathrm{Q} 2}$ \\
\hline$t_{2}<t<t_{3}$ & $S_{3}$ & $D_{\mathrm{S} 3}$ & $Q_{2}$ & $D_{\mathrm{Q} 2}$ \\
\hline$t_{3}<t<t_{4}$ & $S_{3}$ & $S_{3}$ & $Q_{2}$ & $Q_{2}$ \\
\hline$t_{4}<t<t_{5}$ & $S_{3}$ & $S_{3}$ & 0 & $D_{\mathrm{Q} 1}$ \\
\hline$t_{5}<t<t_{6}$ & $S_{3}$ & $S_{3}$ & $Q_{1}$ & $D_{\mathrm{Q} 1}$ \\
\hline \hline
\end{tabular}

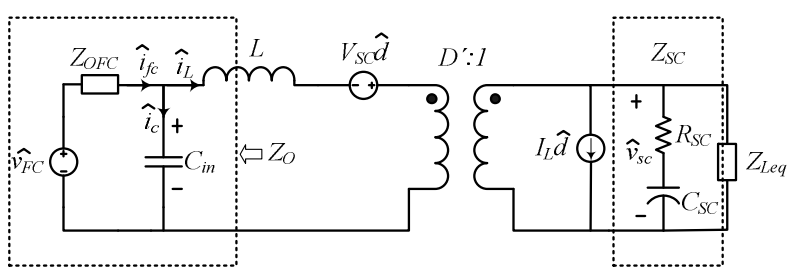

Fig. 4. Small signal model of boost converter with fuel cell and supercapacitor equivalent impedance.

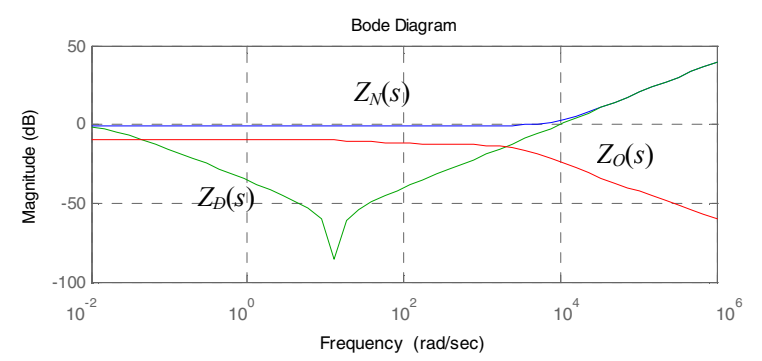

Fig. 5. Impedance analysis.

\section{STABILITY AND CONTROLLER DESIGN}

In general, to guarantee the steady state stability of a fuel cell powered DC-DC converter system, the V-I characteristic of the fuel cell and the locus of the DC-DC converter load power required have to intersect at one point and this sets the operating condition of the system.

In the transient stability analysis, it is more complex because the dynamics of the DC-DC converter is affected by the characteristics of the internal impedance of the fuel cell and the equivalent impedance of the supercapacitor when the closed-loop controller is designed for the primary boost converter. In terms of the equivalent circuit model of fuel cell in [14], Middlebrook's extra element theorem [15] can be used to analyze the effect caused by fuel cell to the dynamics of the converter. The small signal circuit model of boost converter with fuel cell and supercapacitor is shown in Fig. 4, where $Z_{O F C}$ is the output impedance of the fuel cell, $C_{i n}$ is the input capacitor of the boost converter, $Z_{S C}$ is the impedance of supercapacitors bank, and $Z_{L e q}$ is the equivalent load impedance. If the effect caused by $Z_{O}$ and $Z_{S C}$ could be neglected in controller design, as that shown in [14], the following impedance inequalities have to be met:

$$
\left\|Z_{o}\right\|<<\left\|Z_{N}\right\| \text { and }\left\|Z_{o}\right\|<<\left\|Z_{D}\right\|
$$

According to the calculation procedure in Appendix, we can plot the magnitudes of $Z_{O}, Z_{N}$ and $Z_{D}$, respectively, in Fig. 5. It is clear that by connecting the fuel cell and supercapacitor to the DC-DC converter all the transfer functions are modified including the control to output and the line to output. So to design the controllers of the DC-DC converter, the transfer functions are re-deduced considering the fuel cell output impedance and supercapacitor equivalent 


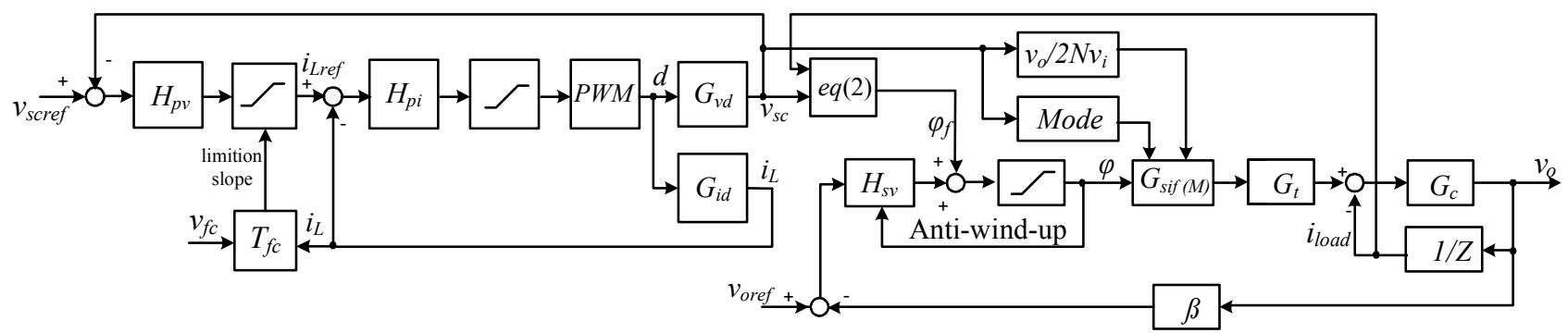

Fig. 6. Block diagram of the control strategy.

impedance. The equations for the boost input current and output voltage transfer functions are presented by (4) and (5).

$$
\begin{aligned}
& G_{i d}(s)=\frac{\hat{i}_{L}(s)}{\hat{d}(s)}= \\
& V_{S C} \frac{Z_{S C} D^{\prime 2}+1}{Z_{O}\left(Z_{S C}+Z_{L e q}\right)+Z_{S C} Z_{L e q} D^{\prime 2}+\left(Z_{S C}+Z_{L e q}\right) L s} \\
& G_{v d}(s)=\frac{\hat{v}_{S C}(s)}{\hat{d}(s)}= \\
& \frac{V_{S C}}{D^{\prime}} \frac{Z_{S C} Z_{L e q} D^{\prime 2}-Z_{O} Z_{S C}-L Z_{S C} S}{Z_{O}\left(Z_{S C}+Z_{L e q}\right)+Z_{S C} Z_{L e q} D^{\prime 2}+\left(Z_{S C}+Z_{L e q}\right) L s}
\end{aligned}
$$

For the two-phase boost converter, the dual loop control scheme is designed. The outer loop is voltage loop, whose output is set to be the current reference for the inner average current loop, shown in Fig. 6. According to the method in [16], we can get the open loop gains, $T_{i}(s)$ and $T_{v}(s)$, for the current loop and voltage loop, as:

$$
\begin{aligned}
& T_{i}(s)=H_{i}(s) \cdot G_{i d}(s) \cdot e^{-T s} \\
& T_{v}(s)=\frac{H_{v}(s) \cdot H_{i}(s) \cdot e^{-T s} \cdot G_{v d}(s)}{1+T_{i}(s)}
\end{aligned}
$$

where $H_{i}(s)$ and $H_{v}(s)$ are the transfer functions of the PI controllers for the current loop and voltage loop, respectively, and $e^{-T s}$ is the delay caused by the sampling, computation and control parameter updating in DSP.

With the open loop transfer functions, we can design the PI compensators using Matlab control toolbox, and get the parameters as:

$$
K_{P V}=20, K_{I v}=1.5, K_{P i}=3.5, K_{I i}=0.6 .
$$

To guarantee the large signal stability during the startup period, a limiter on the input current is calculated based on the output power limitation of the fuel cell.
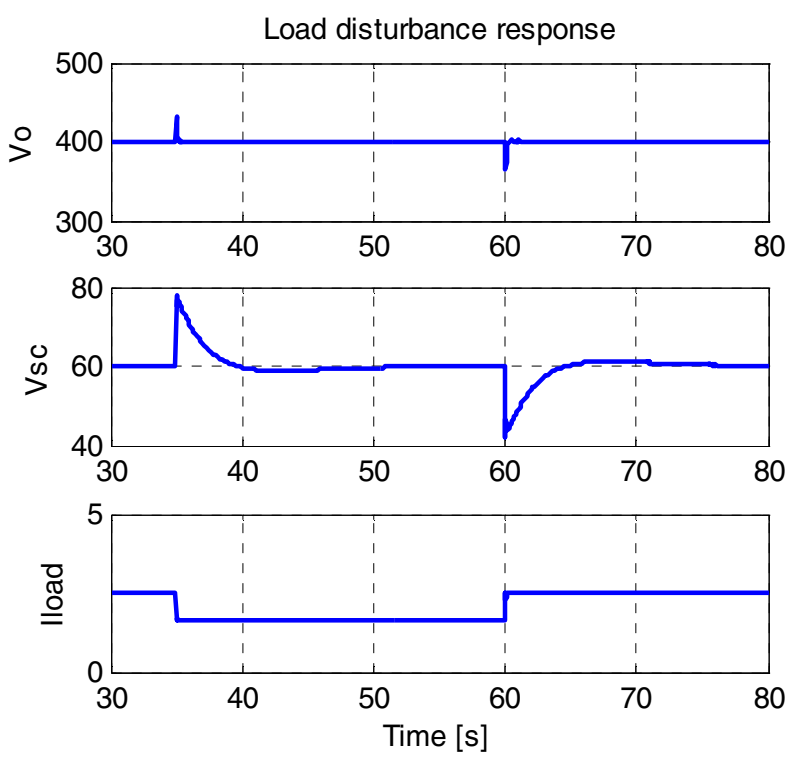

Fig. 7. Simulations of load disturbance response.

Because the PPFHB converter can be seen as a first-order system [11] with the time constant decided by the capacitance of output filter and load impedance, the output voltage controller with the supercapacitor voltage feed-forward is design to keep the output voltage stable.

When the converter operates under buck mode, the constant power charge method is used to charge the supercapacitor. So when the supercapacitor bank is charging, the operating mode is changed from voltage mode to power mode with the voltage limitation that depends on the specification of the supercapacitor. The control scheme requires sampling five variables: $V_{F C}, V_{S C}, V_{D C}, I_{L 1}$ and $I_{L 2}$, which are obtained through the voltage and current transducers. The block diagram for the dc converter system control is shown in Fig. 6. With the compensator parameters design above, the load disturbance response is simulated in the normal operation mode, where energy is delivered from fuel cell and supercapacitor to the high voltage dc bus, shown in Fig. 7, by Matlab/Simulink.

Then, the controllers designed in continuous time domain are converted to discrete time domain by the Euler transformation and implemented in DSP to control the practical system. 


\section{EXPERIMENTAL RESULTS}

In order to verify the effectiveness of the proposed twostage high step-up converter with fuel cell and supercapacitors, as shown in Fig. 2, the corresponding experimental results are provided in this section. A programmable DC power supply is used to simulate the fuel cell for the primary input power source.

Moreover, 24 supercapacitors (BCAP0350, $2.5 \mathrm{~V} / 350 \mathrm{~F}$ ) in series connection are taken as the power storage unit connected in the variable DC bus. In the experimentation, the bidirectional PPFBH converter is design to operate from a variable dc input, $V_{S C}=40 \mathrm{~V}-25 \mathrm{~V}$, to deliver a constant output $V_{D C}=200 \mathrm{~V}$. The energy storage in supercapacitors can be calculated as:

$$
E=\frac{1}{2} C_{S C}\left(V_{1 S C}^{2}-V_{2 S C}^{2}\right)=0.5 \cdot 15 \cdot\left(40^{2}-25^{2}\right)=7312 \mathrm{~J}
$$

So the during the warm-up stage of fuel cell, the energy stored in supercapacitors can be delivered to the load to keep the high voltage dc bus stable.

The digital signal processor (DSP) TMS320F2808 is adopted to implement the close-loop control schemes. The duty cycle and phase-shift signal is generated by DSP and the peripheral logic circuits distribute the driving signals to the corresponding switches in the main circuit.

Based on the analysis in Section III, we can choose the inductance for the two-phase boost converter and make it work in CCM according to (1). For the PPFHB converter, the turns ratio of the transformer and auxiliary inductance should be designed to satisfy the following criteria: 1) at heaviest load condition, to keep the DC bus voltage constant, $\varphi$ is limited under the maximum phase shift angle; 2) Trade-off between the turns ratio and auxiliary inductance is to lower RMS current and extend ZVS operation range. Moreover, the two windings of the coupled inductors are wound on the two outer legs of the EE core with the coupling coefficient $k=0.34$

TABLE II

CONVERTER COMPONENTS AND PARAMETERS

\begin{tabular}{|c|c|}
\hline Switches in boost converter, $S_{1}, S_{2}, S_{\mathrm{r} 1}, S_{\mathrm{r} 2}$ & SUP90N15P $(150 \mathrm{~V} / 100 \mathrm{~A})$ \\
\hline $\begin{array}{r}\text { Switches in PPFHB converter: } S_{3}, S_{4} \\
\qquad Q_{1}, Q_{2}\end{array}$ & $\begin{array}{l}\text { SUP90N15P }(150 \mathrm{~V} / 100 \mathrm{~A}) \\
\text { IRFP450LC }(500 \mathrm{~V} / 14 \mathrm{~A})\end{array}$ \\
\hline Inductors $L_{1}, L_{2}$ & $46 \mathrm{uH}$ \\
\hline Core material and size of $L_{1}, L_{2}$ & Ferrite N87, ETD49 \\
\hline Transformer core material and size & Ferrite PC40, EE55 \\
\hline Transformer turns & $5: 5: 15$ \\
\hline Transformer leakage inductance & $1 \mathrm{uH}$ \\
\hline Inductors $L_{l 1}, L_{l 2}$ and coupling factor & $9 \mathrm{uH}, 0.34$ \\
\hline Core material and size of $L_{l 1}, L_{l 2}$ & Ferrite N27, E40 \\
\hline Output DC capacitor $\left(C_{1}, C_{2}\right)$ & $470 \mathrm{uF} / 350 \mathrm{~V}$ \\
\hline $\begin{array}{l}\text { Input capacitor, } C_{f} \text {, and clamp capacitor } \\
C_{c}\end{array}$ & $1000 \mathrm{uF} / 100 \mathrm{~V}$ \\
\hline Switching frequency $f_{s B}, f_{s P}$ & $20 \mathrm{kHz}, 40 \mathrm{kHz}$ \\
\hline Digital controller & TI TMS320F2808 DSP \\
\hline
\end{tabular}

The one disadvantage of the push-pull-forward circuit is that the voltage stress on the MOSFET is doubled comparing with that in full bridge circuit. The high voltage MOSFET will be with higher on state resistance, $R_{D S(\text { on })}$, which is key to condition loss. But because of soft-switching the switching speed which affects the switching loss is not very critical factor, so we can use the high-current MOSFET with lower $R_{D S(\text { on) }}$ to reduce the conduction loss. The prototype with the specifications given in Table II is designed to illustrate the effectiveness of the proposed two-stage bidirectional converter.

Fig. 8 shows that waveforms of the boost converter under CCM condition with $500 \mathrm{~W}$ output power. We can see that the two-phase structure can reduce the input current ripple comparing with the current ripple through the single leg.

Fig. 9 shows the waveforms of the boost converter under light load condition with the output power $100 \mathrm{~W}$. It is clear that $i_{L 2}$ has the negative part already because of the SCM operation, but the $i_{F C}$ is still positive. If $i_{F C}$ has the negative peak current, the reactive power required will be bigger to cause more power loss in the input capacitors.

Fig. 10 and Fig. 11 show the experimental waveforms of the PPFHB converter working in boost mode and buck mode, respectively, under the condition: $V_{S C}=30 \mathrm{~V}$ and $V_{D C}=200 \mathrm{~V}$. $v_{A B}$ is leading to the $v_{C N}$ in Fig. 10 but they are change the leading-lagging relation in phase in Fig. 11, when the energy is delivered from the DC bus to the supercapacitor side.

Fig. 12, Fig. 13 and Fig. 14 show the dynamic experimental waveforms of two-stage converter system. During the fuel cell warm-up period, the output power is provided by the supercapictors, so the voltage of the supercapacitors reduces from $40 \mathrm{~V}$. But the DC bus voltage, $v_{D C}$, can keep stable at $200 \mathrm{~V}$. Before $V_{S C}$ reaches to $30 \mathrm{~V}$, the warm-up stage of the fuel cell is finished, so fuel cell output current, $i_{F C}$, starts to increase and at the same time the output current of supercapacitors, $i_{S C}$, reduces. The power conversion from fuel cells and supercapacitors can be realized softly and smoothly, as shown in Fig. 12. But if the warm-up stage is too long or the load is too heavy, that means the $V_{S C}$ reduces rapidly below $30 \mathrm{~V}$, the fuel cell will provide the output power and charge the supercapacitors as well. Because of the inner current loop of the two-phase boost converter, $i_{F C}$ is limited to $20 \mathrm{~A}$, and then when the $V_{S C}$ is charged to $30 \mathrm{~V}$, voltage loop of the controller is functional, and the supercapacitors are in standby condition, shown in Fig. 13. The load disturbance response is shown in Fig. 14. So the control scheme designed in Section IV is validated. The efficiency of the whole system is above $87 \%$ in the entire load range, and the peak efficiency is $92 \%$.

\section{CONCLUSION}

This paper proposed the multi-stage converter structure with fuel cell and supercapacitors as a hybrid system. Converter design, control scheme analysis and design are implemented. The topology is based on the interleaved twophase boost converter and a novel PPFHB converter to provide constant DC bus voltage and can realize bidirectional 


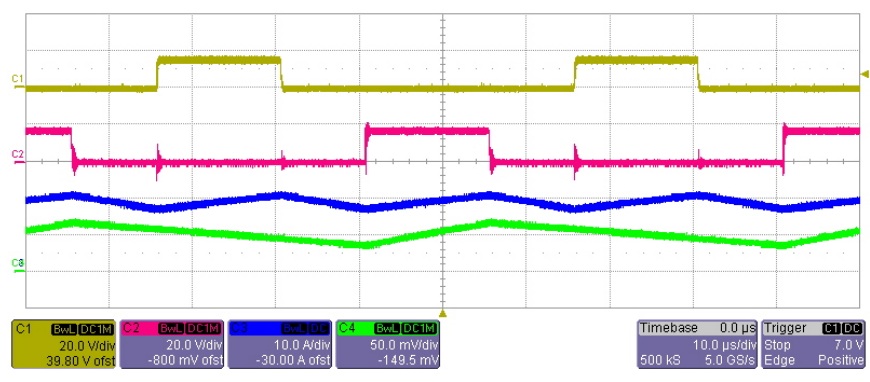

Fig. 8. Waveforms of the two-phase boost converter under CCM. CH1: $V_{g S}$ (yellow), $20 \mathrm{~V} /$ div; $\mathrm{CH} 2: V_{g S 2}$ (red), $20 \mathrm{~V} /$ div; $\mathrm{CH} 3: i_{F C}$ (blue), $10 \mathrm{~A} / \mathrm{div}$; $\mathrm{CH} 4: i_{L 2}$ (green), $10 \mathrm{~A} /$ div. (Time base: $10 u \mathrm{~s} / \mathrm{div}$ )

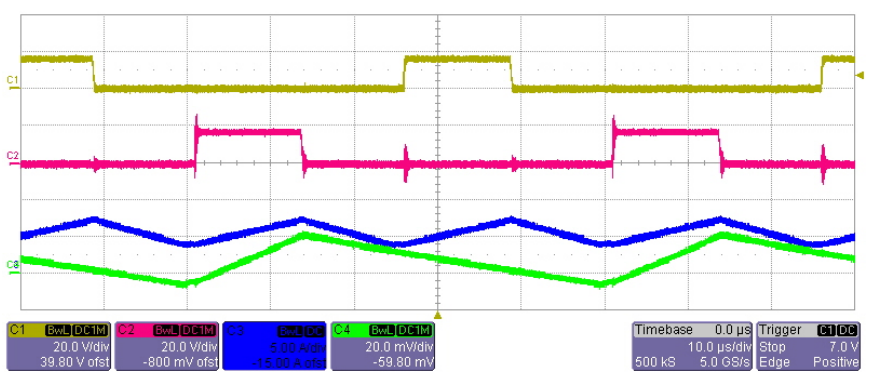

Fig. 9. Waveforms of the two-phase boost converter under light load condition. CH1: $V_{g S 1}$ (yellow), $20 \mathrm{~V} /$ div; $\mathrm{CH} 2: V_{g S 2}$ (red), $20 \mathrm{~V} /$ div; $\mathrm{CH} 3: i_{F C}$ (blue), $5 \mathrm{~A} /$ div; $\mathrm{CH} 4: i_{L 2}$ (green), $5 \mathrm{~A} / \mathrm{div}$. (Time base: $10 u \mathrm{~s} / \mathrm{div}$ )

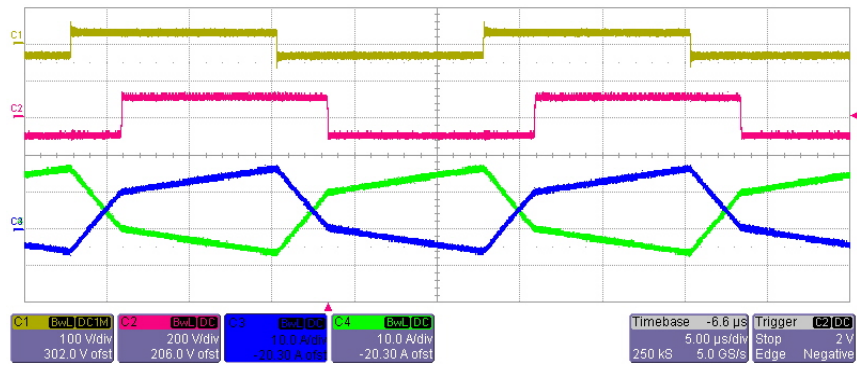

Fig. 10. Waveforms of the PPFHB converter working in boost mode. $\mathrm{CH} 1$ : $V_{A B}$ (yellow), $100 \mathrm{~V} /$ div; $\mathrm{CH} 2: V_{C N}$ (red), $200 \mathrm{~V} / \mathrm{div}$; $\mathrm{CH} 3: i_{L P I}$ (blue), 10 A/div; CH4: $i_{L P 2}$ (green), $100 \mathrm{~V} /$ div. (Time base: $5 u$ s/div)

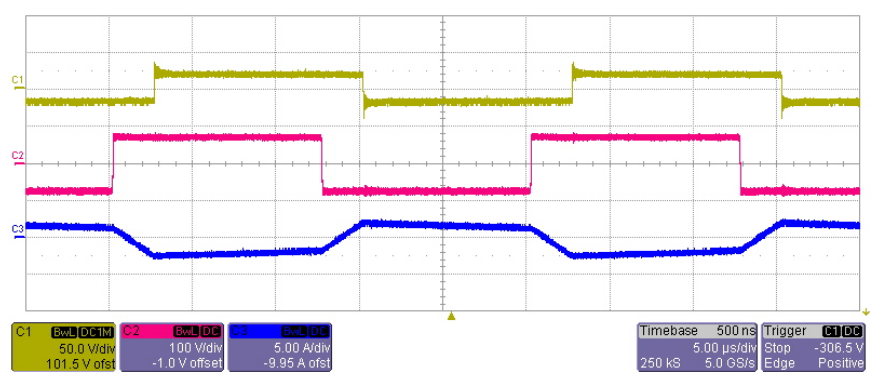

Fig. 11. Waveforms of the PPFHB converter working in buck mode. $\mathrm{CH} 1$ : $V_{A B}$ (yellow), $50 \mathrm{~V} / \mathrm{div} ; \mathrm{CH} 2: V_{C N}$ (red), $100 \mathrm{~V} / \mathrm{div}$; $\mathrm{CH} 3: i_{S}$ (blue), $5 \mathrm{~A} / \mathrm{div}$. (Time base: 5 us/div)

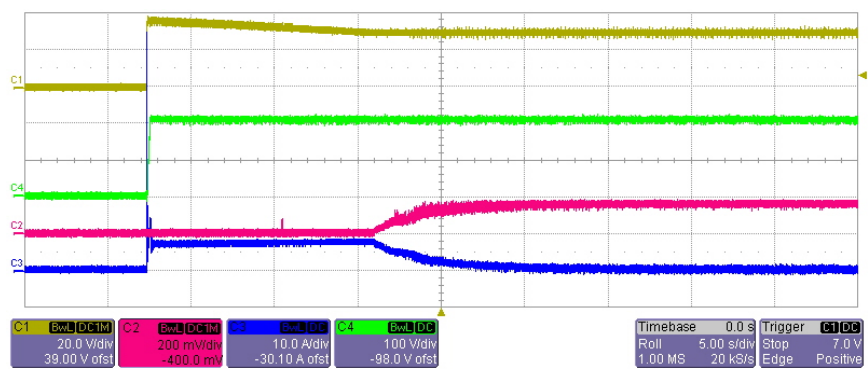

Fig. 12. Dynamic state waveforms under normal condition. $\mathrm{CH} 1: V_{\mathrm{SC}}$ (yellow), $20 \mathrm{~V} / \mathrm{div} ; \mathrm{CH} 2: i_{F C}$ (red), $10 \mathrm{~A} / \mathrm{div} ; \mathrm{CH} 3: i_{S C}$ (blue), $10 \mathrm{~A} / \mathrm{div} ; \mathrm{CH} 4$ : $V_{D C}$ (green), $100 \mathrm{~V} /$ div. (Time base: $5 \mathrm{~s} /$ div)

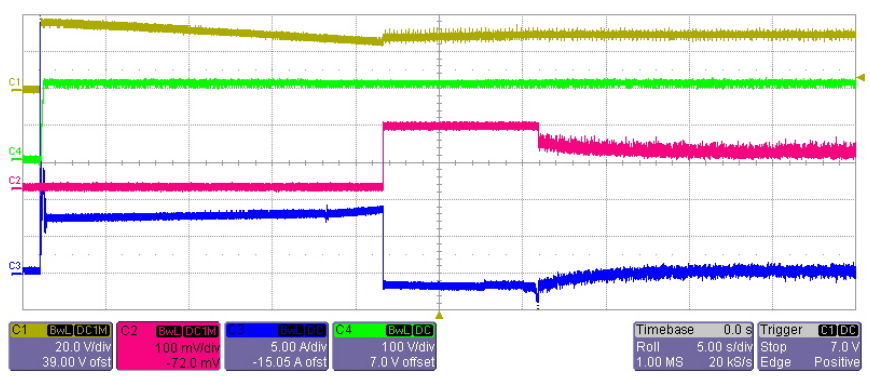

Fig. 13. Dynamic state waveforms under heavy load condition. $\mathrm{CH} 1: V_{\mathrm{SC}}$ (yellow), $20 \mathrm{~V} / \mathrm{div}$; $\mathrm{CH} 2: i_{F C}$ (red), $10 \mathrm{~A} / \mathrm{div} ; \mathrm{CH} 3: i_{S C}$ (blue), $10 \mathrm{~A} / \mathrm{div} ; \mathrm{CH} 4$ : $V_{D C}$ (green), $100 \mathrm{~V} /$ div. (Time base: $5 \mathrm{~s} /$ div)

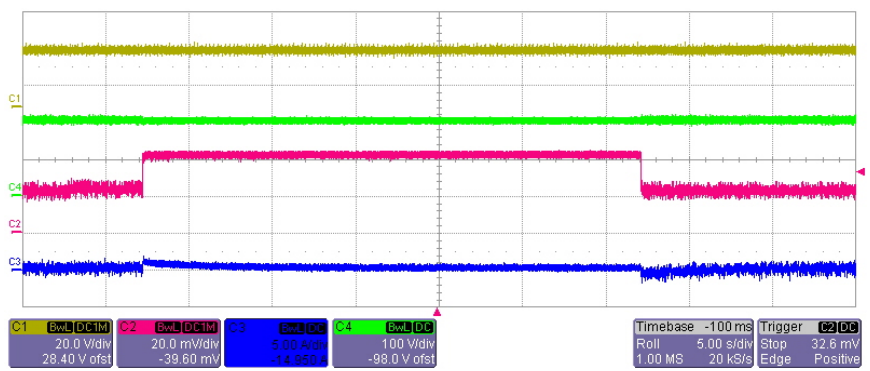

Fig. 14. The load disturbance response: load current steps up from $1 \mathrm{~A}$ to $2 \mathrm{~A}$ and steps down. $\mathrm{CH} 1: V_{\mathrm{SC}}$ (yellow), $20 \mathrm{~V} /$ div; $\mathrm{CH} 2$ : load current (red), 1 $\mathrm{A} /$ div; $\mathrm{CH} 3: i_{S C}$ (blue), $5 \mathrm{~A} /$ div; $\mathrm{CH} 4: V_{D C}$ (green), $100 \mathrm{~V} /$ div. (Time base: 5 s/div)

power flow control. The controller is a fully digital DSP based system. The effects of the fuel cell output impedance and the impedance of supercapacitor to the system stability are considered during the controller design. The topology and control strategy for the hybrid system are verified by the simulations and experimental results.

\section{APPENDIX}

According to the model of fuel cell drawn in [14], we can get the $Z_{F C O}, Z_{O}$ and $Z_{S C}$ as: 


$$
\begin{aligned}
& Z_{F C O}= \\
& \frac{s^{2}\left(R_{m} R_{p 1} R_{p 2} C_{1} C_{2}\right)}{s^{2}\left(R_{p 1} R_{p 2} C_{1} C_{2}\right)+s\left(R_{p 1} C_{1}+R_{p 2} C_{2}\right)+1}+ \\
& \frac{s\left(R_{m}\left(R_{p 1} C_{1}+R_{p 2} C_{2}\right)+R_{p 1} R_{p 2}\left(C_{1}+C_{2}\right)\right)}{s^{2}\left(R_{p 1} R_{p 2} C_{1} C_{2}\right)+s\left(R_{p 1} C_{1}+R_{p 2} C_{2}\right)+1}+ \\
& \frac{R_{m}+R_{p 1}+R_{p 2}}{s^{2}\left(R_{p 1} R_{p 2} C_{1} C_{2}\right)+s\left(R_{p 1} C_{1}+R_{p 2} C_{2}\right)+1} \\
& Z_{O}=Z_{F C O} \| \frac{1}{C_{i n} \cdot s+R_{C i n}} \\
& Z_{S C}=\frac{1}{C_{S C} \cdot s+R_{S C}}
\end{aligned}
$$

where $R_{m}$ is the resistance of the membrane, $R_{p 1}-C_{1}$ and $R_{p 2^{-}}$ $C_{2}$ are the time constants of each electrode of the fuel cell.

Based on the Middlebrook's extra element theorem [15], $Z_{N}(s)$ and $Z_{D}(s)$ of the two-phase boost converter are given by:

$$
\begin{gathered}
Z_{N}(s)=-D^{\prime 2} Z_{L e q}\left(1-\frac{s L}{D^{\prime 2} Z_{L e q}}\right) \\
Z_{D}(s)=D^{\prime 2} Z_{L e q}\left(\frac{1+s \frac{L}{D^{\prime 2} Z_{L e q}}+s^{2} \frac{L C_{S C}}{D^{\prime 2}}}{1+s Z_{L e q} C_{S C}}\right)
\end{gathered}
$$

where the duty cycle of steady state is $D$ and $D^{\prime}$ equals to $1-D^{\prime}$.

The equivalent circuit parameters of the fuel cell, supercapacitor and boost converter are listed in Table III. So we can plot the Fig. 5 in Matlab.

TABLE III

\begin{tabular}{c|c|c|c|c}
\hline \hline$R_{m}$ & $R_{p 1}$ & $C_{1}$ & $R_{p 2}$ & $C_{2}$ \\
\hline $16.8 m \Omega$ & $78.6 m \Omega$ & $258.9 m \mathrm{~F}$ & $218.75 \mathrm{~m} \Omega$ & $556.8 \mathrm{mF}$ \\
\hline \hline$L$ & $C_{S C}$ & $P_{O}$ & $V_{O}$ & $D^{\prime}$ \\
\hline $100 u \mathrm{H}$ & $15 \mathrm{~F}$ & $1000 \mathrm{~W}$ & $40 \mathrm{~V}$ & 0.5 \\
\hline \hline
\end{tabular}

\section{REFERENCES}

[1] X. Yu, M. R. Starke, L. M. Tolbert, and B. Ozpineci, "Fuel cell power conditioning for electric power applications: a summary," IET Electric Power Applications, vol. 1, pp. 643-656, 2007.

[2] M. Becherif, M.Y. Ayad and A. Miraoui, "Modeling and passivitybased control of hybrid sources: fuel cell and supercapacitors," Conference Record of the 2006 IEEE Industry Applications Conference Forty-First IAS Annual Meeting, vol.3, pp. 1134-1139, 2006.

[3] P. Thounthong, S. Rael, and B. Davat, "Control strategy of fuel cell and supercapacitors association for a distributed generation system,"IEEE
Transactions on Industrial Electronics, vol. 56, no. 6, pp. 3225-3233, 2007.

[4] O.C. Onara, M. Uzunoglu and M.S. Alam, "Modeling, control and simulation of an autonomous wind turbine/photovoltaic/fuel cell/ultracapacitor hybrid power system," Journal of Power Sources, vol.185, no. 2, pp. 1273-1283, 2008.

[5] D. Liu and H. Li, "A ZVS bi-directional DC-DC converter for multiple energy storage elements," IEEE Trans. Power Electron., vol. 21, no. 5, pp. 1513-1517, Sep. 2006.

[6] H. Tao, A. Kotsopoulos, J. L. Duarte and M. A. M. Hendrix, "Transformer-coupled multi-port ZVS bidirectional DC-DC converter with wide input range," IEEE Transactions on Power Electronics, vol. 23 , no. 2 , pp. $771-781,2008$.

[7] C. Zhao, S. D. Round, J. W. Kolar, "An isolated three-port bidirectional DC-DC converter with decoupled power flow management," IEEE Transactions on Power Electronics, vol. 23, no. 5, pp. 2443-2453, 2008.

[8] J. Wang, F. Z. Peng, J. Anderson, A. Joseph and R. Buffenbarger, "Low cost fuel cell converter system for residential power generation," IEEE Transactions on Power Electronics, vol. 19, no. 5, pp. 13151322, 2004.

[9] M. H. Todorovic, L. Palma and P. N. Enjeti, "Design of a wide input range DC-DC converter with a robust power control scheme suitable for fuel cell power conversion," IEEE Transactions on Industrial Electronics, vol. 55, no. 3, pp. 1247-1255, 2008.

[10] Jinseok Hong, Sungyoon Jung, Pham Dai Thang and Kwanghee Nam "Hybridization fuel cell with supercapacitor for FCEV," Annual IEEE Applied Power Electronics Conference and Exposition, pp. 286-290, 2008.

[11] Z. Zhang, O. C. Thomsen, M. A. E. Andersen, "Analysis and design of PPFHB bidirectional DC-DC converter with coupled inductors," in the $13^{\text {th }}$ European Conference on Power Electronics and Applications (EPE 2009), Spain, 2009

[12] W. Yu and J. Lai, "Ultra high efficiency bidirectional dc-dc converter with multi-frequency pulse width modulation," Annual IEEE Applied Power Electronics Conference and Exposition, pp. 1079-1084, 2008.

[13] Z. Zhang, O. C. Thomsen, M. A. E. Andersen, "A novel PPFHB bidirectional DC-DC converter for super-capacitor application," in the International Conference on Clean Electrical Power (ICCEP 2009), Italy, 2009.

[14] S. C. Page, A. H. Anbuky, S. P. Krumdieck, and J. Brouwer, "Test method and equivalent circuit modeling of a PEM fuel cell in a passive state," IEEE Transactions on Energy Conversion, vol. 22, no.3, pp. 764-773, 2007.

[15] R. Erickson, D Maksimovic, Fundamentals of Power Electronics (secondary edition), Springer, pp.378-385, 2001.

[16] X. Huang, X. Wang, T. Nergaard, J. Lai, X. Xu and L. Zhu, "Parasitic ringing and design issues of digitally controlled high power interleaved boost converter," IEEE Transactions on Power Electronics, vol. 19, no. 5, pp. 1341-1352, 2004 